\title{
ORGANIZATIONAL REFORMATION OF AGRIBUSINESS ENTITIES IN UKRAINE
}

\author{
Anatolii Mazur ${ }^{1}$ \\ Vinnytsia National Agrarian University, Ukraine \\ Valerii Bondarenko \\ Vinnytsia Institute of Trade and Economics, Kyiv National University of Trade and Economics, Ukraine \\ Serhii Mazur ${ }^{3}$ \\ Vinnytsia National Agrarian University, Ukraine
}

\begin{abstract}
The article considers urgent issues of organizational reformation of economic entities of the AIC with a view to their optimization to requirements of an advanced development model of the agrarian economy. The importance of mentioned topics is determined by the content and themes of conducted system transformations in the agricultural sector of the agrarian economy towards the formation of a competitive and economically attractive system of management. Research object is subjects of various organizational forms of management in the agrarian sector of the economy in the process of their structural reforming. The purpose of the research is to substantiate development processes of AIC enterprises in a transition economy through the organizational modelling of production organization forms in terms of formation of an advanced model of a reproduction of the agrarian economy. The methodology of the research in this article is formed on the compliance with the economic development demands through the relevant laws. Their requirement is realized through the compliance with the requirements of scientific principles as guiding ideas for the implementation of business practices. The interrelation of management functions and scientific principles allows determining a set of research methods for the stated issue. It should be stressed that scientific methodology of this research also includes the use of factors of placement of agrarian enterprises in space and a set of factors of the external and internal influence that make a direct impact on the efficiency of functioning, in particular, small business forms. As a research result, the paper highlights a bipolar structure of the agrarian sector where powerful agrarian-industrial formations and small agricultural enterprises and households of the population coexist in parallel. It quite clearly distinguishes creation of cooperatives, which are considered a basis and effective form of business in rural areas that ensures rural development. In the authors' opinion, among the presented business forms in rural areas, which operate in parallel, family farming enterprises can become the most perspective in the future. Today, agricultural enterprises, which, on the basis of mergers or acquisitions, were included in the composition of agricultural holdings, generally do not know their status, and hence they actually lose their economic independence. The practical importance of this publication is the possibility of allocating economically feasible forms of organizational development of the AIC and, on this basis, development and introduction of effective mechanisms for managing their support from the hierarchical authorities.
\end{abstract}

Key words: agroholdings, state enterprises, farming enterprises, households, cooperation, family farming enterprise.

JEL Classification: Q13, Q18

\footnotetext{
Corresponding author:

${ }^{1}$ Department of Agricultural Management, Vinnytsia National Agrarian University.

E-mail: bondarenkovalm@gmail.com.

${ }^{2}$ Department of Marketing and Advertising, Vinnytsia Institute of Trade and Economics, Kyiv National University of Trade and Economics. E-mail: BondarenkoVM@vtei.com.ua.

${ }^{3}$ Department of Management of Foreign Economic Activity, Hotel and Catering Industry and Tourism, Vinnytsia National Agrarian University.

E-mail: BondarenkoVM@vtei.com.ua.
} 


\section{Introduction}

Integration of the agrarian economy of Ukraine in pan-European and global economic space objectively requires determination and consideration of the main priorities, existent trends, and determinant features of the modern agrarian development. In this view, important is the issue of formation of institutional mechanisms and infrastructure of the agrarian economy at the state level and at the level of AIC enterprises. An important essence of these processes is a structural reformation of enterprises of agrarian direction towards the minimization of load on natural resources, reducing the cost of maintaining infrastructure and planning a possible extended economic reproduction on an innovative basis. Scientific and practical importance of solving these issues determined the relevance of the chosen research topic.

The purpose of the research is to substantiate development processes of AIC enterprises in a transition economy through the organizational modelling of production organization forms in terms of formation of an advanced model of a reproduction of the agrarian economy.

The methodological basis of the research consists of fundamental provisions of modern theory, scholarly works of foreign and domestic scientists, which reveal processes of reformation of agrarian economic systems and substantiate specifics of modern structural transformations. Practical solution of the tasks set in the article was carried out from the standpoint of the system approach and the use of the following research methods: monographic - to study and generalize theoretical and methodological foundations of the conceptual content of the restructuring of agrarian enterprises; statistical to characterize evolution and structural shifts of agrarian formations; organizational modelling - to substantiate rational structures of organization of agricultural production.

Works of famous Ukrainian scientists-agrarians are devoted to solving the specified issues of organizational reformation of AIC enterprises: Borodina O. M. (formation of scientific and organizational fundamentals of rural development); Bondarenko V. M. (dairy farming development); Hubeni Yu. Ye. (development of rural areas); Zhyhadlo O. A. (efficiency of the sectoral structure of enterprises of different business legal structures); Zbarskyi V. K. (private peasant farms in the formation of small forms of management); Mazur A. H. (relevant issues of development of agroindustrial production in terms of system transformation changes); Malik M. Y. (enterprise and development of rural areas); Kyrylenko H. M. (structural reforms in the countryside and world experience, Ukrainian realities); Riabokon V. P. (development of social infrastructure of rural areas); Svynous I. V. (economic aspects of operation of private peasant farms); Lopatynskyi Yu. M. (transformation of the agrarian sector: institutional foundations); Mesel-Veseliak V. Ya. (agrarian reform and organizational and economic transformations in agriculture); Mochernyi S. V. (models of transformational processes of the economy: theoretical and methodological aspects), as well as famous foreign scientists: C. R. McConnell (Economics: Principles, Problems, and Policies); H. Simon (Organizations); H. Koontz (Management: A Systems and Contingency Analysis of Managerial Functions); M. Mescon (Management), and others. However, the issues of organization of reformation of agribusiness entities in Ukraine remain insufficiently studied and require further elaboration.

\section{Development of organizational forms of management in the AIC}

The evolution of organizational forms of management in the AIC is fairly associated with the onset of largescale transformations in the national economy. In this case, researchers distinguish three stages of agrarian transformations: the first - (1991-1999), the second (2000-2004), and the third one - since 2004 (Fig. 1).

During the first stage, preconditions for denationalization and privatization of land and other property of collective and state agricultural enterprises and their reorganization were created. Kolkhozes and sovkhozes were reformed into collective agricultural enterprises (CAE), which unsolder their land and property among their members (Buriak, 2001).

The inconsistent and self-flowing nature of the transformation processes at the first stage of reform has led to a sharp decline in agricultural production. In 1999, gross agricultural products in all categories of farms accounted for $49 \%$ of the level of 1990 , including $28 \%$ for agricultural enterprises. In the households, the volume of production remained almost at the level of 1990 (98\%).

Enterprises with private property and a collective form of production organization

In 2000, the second stage of agrarian transformation began, which is associated with the December (1999) Decree of the President of Ukraine "On Urgent Measures to Accelerate Reform of the Agrarian Sector of the Economy”. In accordance with this Decree, land shares were transformed into private land plots that had specifically defined physical boundaries. At the same time, a part of the peasants seized their plots for selfmanagement. Collective enterprises were liquidated and new productive formations were created on their production assets and private land plots: limited liability companies, farms, agricultural production cooperatives, public and private joint-stock companies, private peasant farms. Organizational changes in production were accompanied by the liberalization of trade in the agricultural market, the reduction of state interference in 


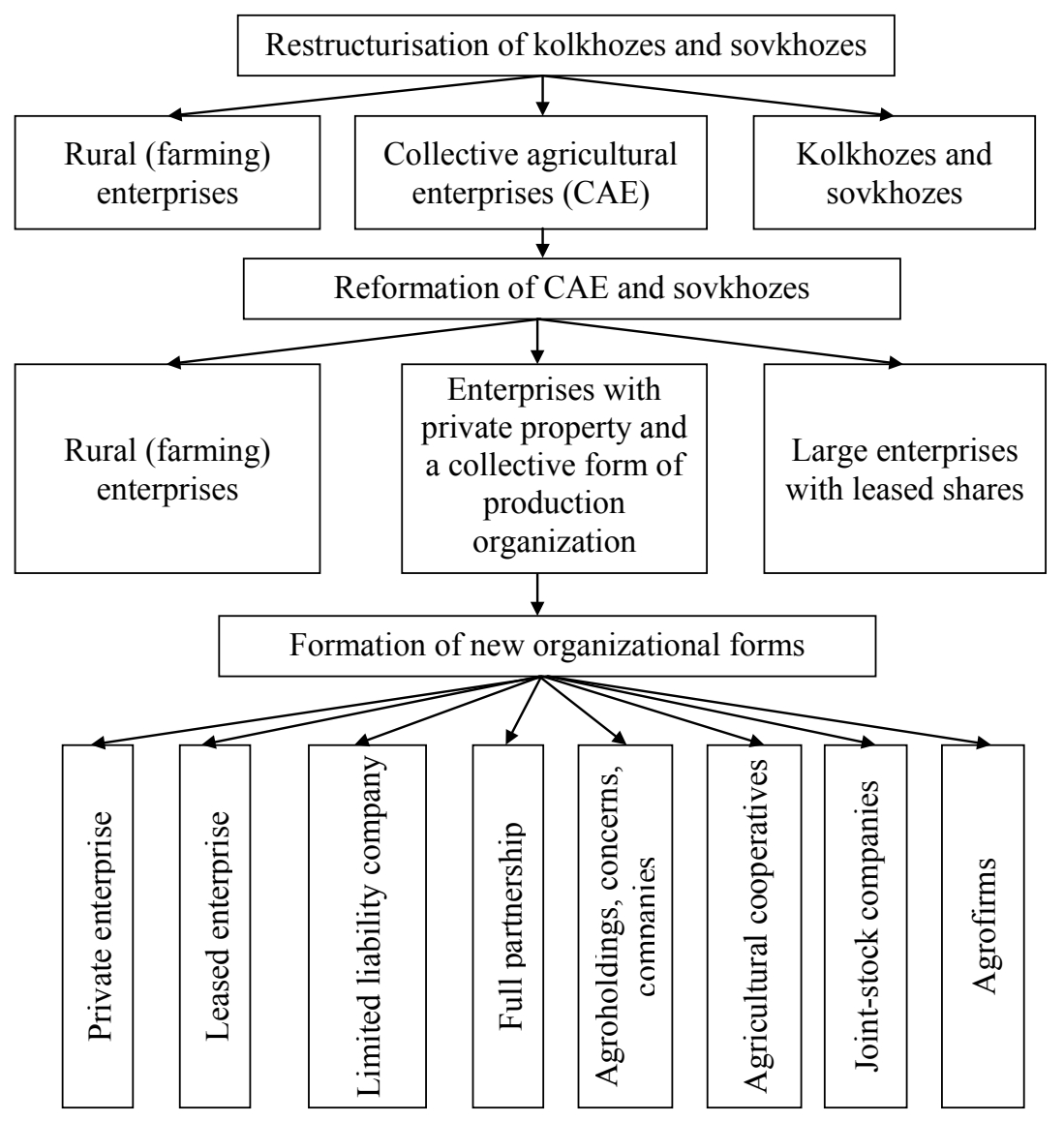

Fig. 1. Evolution of forms of ownership in the AIC

Source: the author's development

the organization of production of material and technical resources, and the positive changes in agricultural price indices relative to the prices of material and technical resources (Andriichuk, 2012; Kovalenko, 2012; Holyshev, 2000; Kulyniak, 210; Pylypenko, 2008).

Since 2004, in the agrarian sector of the economy, there are processes that characterize the third stage of transformation changes - the intensification of agrarian production based on the concentration of agricultural land and property.

If the first stage was associated with the transformation of kolkhozes into collective agricultural enterprises (CAEs), the second - with the transformation of CAEs into new private organizational forms of management, and these two stages were initiated "from upstairs" and carried out imperatively on the basis of relevant state decisions, then the third stage of the restructuring came from "grassroots", spontaneously, and is carried out in an evolutionary way, even without the formally proclaimed appropriate legal support.

These processes are the result of the incompleteness of institutional transformations, which opened the possibility of establishing shadow control over the distribution of the property of former collective farms and agricultural land and the formation of a shadow land market. Concentration processes through land lease and its sale-purchase develop spontaneously by consolidating large amounts of agricultural land in the hands of individual legal entities and individuals. On controlled lands, through the involvement of industrial and commercial and financial capital, horizontally and vertically integrated export-oriented structures are formed, sometimes by type of land latifundia engaged in multi-profile operations (often from the supply of primary production resources - to processing and exports) on tens and hundreds of thousands of hectares of leased lands (Buriak, 2001).

\section{The role of large agroformations in agribusiness}

The concentration of land resources has led to the formation of new forms of management in agrarian production, that is, the outline of the main ones (Fig. 2).

As it is shown in Fig. 2, economic and social differentiation of agricultural producers has led to the formation of a bipolar structure of agricultural sector in many regions of Ukraine, where powerful agrarianindustrial formations and small agricultural enterprises and households of the population coexist in parallel. At 


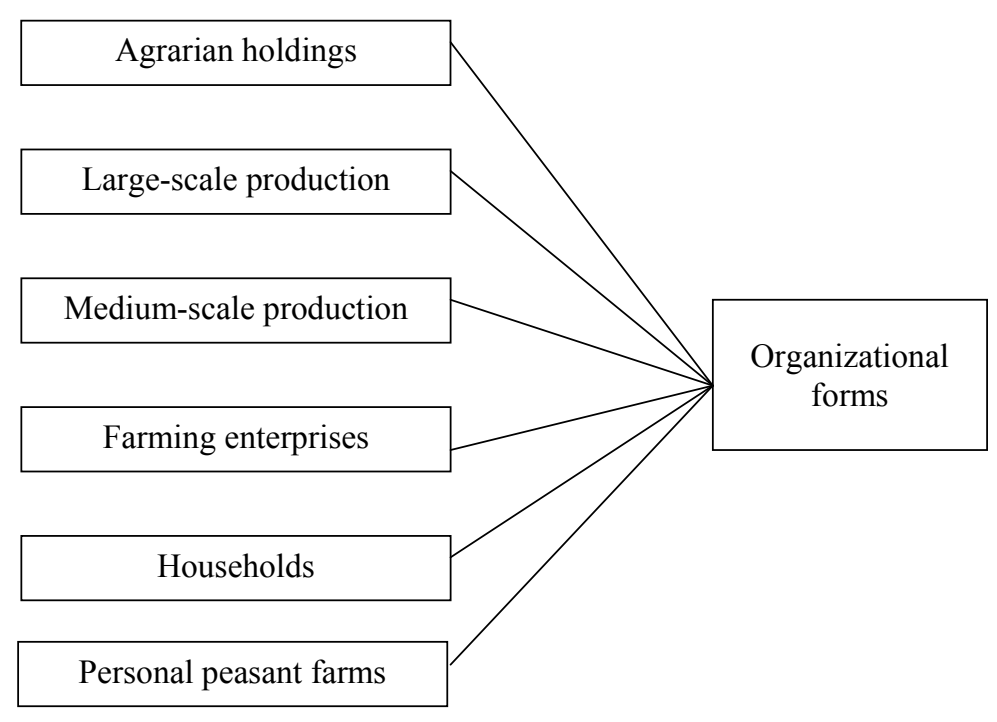

Fig. 2. Forms of management in agribusiness

the same time, the basis of economic growth is provided by large integrated structures, the organizational forms of which are: concerns, companies, agriholdings, and financial industrial groups. So, PAT "Concern Khlibprom” unites 14 enterprises of Lviv, Vinnytsia, Ivano-Frankivsk, Rivne, and Cherkasy regions of Ukraine and is among the leaders of domestic producers of bread and bakery products (Ukrainian market share is $7.5 \%$ ). Agro-industrial group PAT "Mironivsky Hliboproduct" specializes in the production of poultry meat, integrating the entire production chain. An important influence on the development of the economy of Ukraine, in whole, and agrarian one, in particular, is made by SE UVC "Nemiroff”. In 2002, this company realized 8.3 million dal of vodka products in the amount of 480 million USD in the domestic and foreign markets.

In recent years, integrated structures based on agroholdings have become widespread. To date, there are more than 50 agroholdings in Ukraine. The biggest of them are: TOV "Ukrainian Agrarian Investments" (330 thousand hectares), PAT "Illich Steel and Iron Works" (225 thousand hectares), SE "Narkom-Ahro" (200 thousand hectares), PAT "Mironivsky Hliboproduct" (180 thousand hectares), PAT “Rise-Maksymko" (160 thousand hectares), MRIYA Agro Holding (158 thousand hectares), PAT "Privat-Ahroholding" (150 thousand hectares), Agroton (150 thousand hectares), Loture Agro (150 thousand hectares), Rise-Agro (130 thousand hectares), Dakor Agroholding (106 thousand hectares), Ukrros (105 thousand hectares), Ukrzernoprom-Agro (100 thousand hectares), AIC "Shakhtar", Zasyadko Mine (100 thousand hectares), and others. In general, agroholdings control about 5 million hectares or almost $15 \%$ of the arable land in Ukraine (Andriichuk, 2012).
It should be also emphasized that agroholdings in Ukraine are purely business projects, the main purpose of which is to generate profits and increase the capital of their founders. Support and development of rural infrastructure have never been a function of agroholdings since the founders or owners of agroholdings, as a rule, do not live in places of agribusiness and they do not have the need to use rural infrastructure. Indicators of the effectiveness of agroholdings are presented in Table 1.

The main form of the founding of agroholdings is the lease of land plots. According to the State Committee of Ukraine for Land Resources, the owners of the rights to land parcels (shares), certified by a certificate of ownership, or certificate of title under the land transfer act, have already concluded 4614 thousand lease agreements, which is $67 \%$ of the received certificates. By the duration, the agreements are concluded for: 1-3 years - 490 thousand $(10 \%)$; $4-5$ years 2258 thousand $(48.9 \%)$; 6-10 years -1414 thousand $(30.6 \%) ; 10$ years and more -489 thousand $(10.3 \%)$ (Kyrylenko, 2016).

Thus, agroholdings are not interested in long-term capital investments in the development of agricultural infrastructure even in those cases when such investments can significantly improve the efficiency of agricultural production as the holding does not have sufficiently reliable guarantees of the use of leased land plots.

The development of multi-unit agricultural enterprises dates back to the 90s when they were 34 . They are now also present in the agrarian market, in particular, the research and production multi-unit agricultural enterprise "Pushcha-Vodytsia", the multiunit agricultural enterprise "Kometa" of Brovary district of Kyiv region, the multi-unit agricultural enterprise "Vynohradnyi" of Simferopol region of AR of Crimea, and others. As one of the forms of inter-farm cooperation, multi-unit agricultural enterprises lost 
Table 1

The largest agricultural producers in Ukraine for 2016

\begin{tabular}{|c|l|c|c|c|c|}
\hline \multirow{2}{*}{$\begin{array}{c}\text { Place in } \\
\text { rating }\end{array}$} & \multicolumn{1}{|c|}{ Company } & \multicolumn{2}{|c|}{ Revenue, million UAH } & Growth rate of & \multirow{2}{*}{ Profits margin, \% } \\
\cline { 2 - 5 } & & 2011 & 2016 & 135.2 & 7.2 \\
\hline 8. & Kernee & 15816.8 & 22040.6 & 144.5 & 28.5 \\
\hline 15. & UkrLand Farminq & 10740 & 16250 & 114.6 & 22.1 \\
\hline 23. & Mironivsky Hliboproduct & 9820.2 & 11250.3 & 234.2 & 0.0 \\
\hline 25. & Nibulon & 5585 & 10740 & 190.2 & 0.5 \\
\hline 29. & Bunge Ukraine & 7681.6 & 9620 & 105.7 & 16.8 \\
\hline 35. & Rochen & 6416.2 & 8120 & 126.5 & 5.9 \\
\hline 36. & Carqil Ukraine & 4706.3 & 6135.1 & 130.4 & $7-0.9$ \\
\hline 52. & Serna & 3100 & 5460 & 176.1 & 11.0 \\
\hline 58. & Kreatin & 1543.8 & 2598.5 & 168.3 & 0.2 \\
\hline 118. & Oliyar & 1668.6 & 1895.7 & 113.6 & 9.8 \\
\hline 149. & Ahromars & 1866 & 8478.4 & 79.2 & -2.0 \\
\hline 178. & Delta Wilmar CIS & 1165.6 & 1320 & 113.2 & 11.0 \\
\hline 189. & Ukrainian Agrarian Investments & & & & \\
\hline
\end{tabular}

Source: Forbes Ukraine. Access mode: forbes nef.ua

their significance in the process of combining agriculture with other branches of the AIC, in other words, they were transformed into more progressive integration structures. The reason for this is the reduction of state support for their existence on the basis of administrative management methods.

Middle agricultural enterprises are also characterized by organizational processes. This, first of all, concerns farming enterprises.

An official definition of a farming enterprise as a new organizational structure of the AIC was given by the State Agro-Industrial Committee of the Ukrainian SSR with the formulation that "a farming enterprise is an integrated formation, which is created on the basis of one kolkhoz or sovkhoz with high level of development of agricultural production and a wide network of subsidiary enterprises and industries, including the processing of products, trade with the preservation of economic independence" (State Industrial Committee, 1988)

The emergence of farming enterprises occurs in 1991 when 87 agro-industrial enterprises were operating in the AIC of Ukraine, of which 54 were formed on the basis of kolkhozes, 14 - on the basis of sovkhozes, and 19 - by combining several agricultural, processing, and other enterprises and organizations. In 1992, there were already more than 100 farming enterprises in Ukraine, and in 1996 - 240. The trend of agribusiness growth is also observed today. According to the scientific publications, their total number is about 300 .

The emergence of a farming enterprise as a subject of agrarian business is dictated by the desire of agricultural producers to have their own trading network, independently determine the scope of production activity, freely dispose of products and funds, and enter the food market independently (Parsiak, 2004).

\section{Development of small forms of management in the countryside}

The dynamics of the structure of gross agricultural output, more than $60 \%$ of which is produced in households, prompts the question of the appropriateness of attracting such households to the processes of agrarianindustrial integration. These small-scale producers, vulnerable to the dynamic influences of environmental factors (scientific and technological advance, availability of sources of financing, demand in local markets, etc.) and any manifestations of stagnation, the loss of operational communications with the environment is one of the first steps towards regression. Stability of the positions of such small agricultural enterprises is always relative and in order to preserve their viability, they must, with an appropriate periodicity, adapt their size and internal configuration to new challenges and threats.

The generalization of research into the development of agricultural production in rural households allows suggesting that this sector of the economy has practically reached its growth by mobilizing the domestic resources of rural families and cooperation with agricultural enterprises. Households are forced to deal with selfexploitation and illegal forms of resource conservation, mainly at the expense of agricultural enterprises, causing material damage to enterprises, where they themselves work, often causing territorial conflicts at the level of the rural community. A detachment of households from markets deprives their owners of incentives for the development of commodity production, forcing them to lead semi-subsistence farming. Not being competitors for large agricultural enterprises due to the difference in the sectoral structure and specialization, households are increasing the production of these products, which is decreasing in large and medium agrarian enterprises (Bohotov, 2008). 
It is from these positions that they become the object of the economic interest of processing enterprises that restore their own raw material base. Owners of personal processing enterprises are interested in agro-industrial integration, which involves a transparent and efficient distribution of the final management results. At the same time, integrational links of households with public production should foresee:

- organizational and economic principles for ensuring the material conditions of production in households;

- economic incentives for the development of agricultural production in households, taking into account objective differences in the conditions of operation;

- assessment and distribution of the results of enterprises of this category both in terms of production volumes in them, and of their state and role in the reimbursement of production costs of households by the public economy. This is ensured by the development of the cooperative movement in the countryside, in particular, the creation of production and service cooperatives.

Creation of cooperatives should be considered the basis and effective form of management in rural areas that ensures rural development. Only in Vinnytsia region today there are 83 agricultural cooperatives, of which 43 are dairy, 2 - meat, 5 - fruit and vegetable, 9 land cultivation, and others -25 . The biggest number of agricultural service cooperatives is established in Khmelnytskyi (21), Zhmerynka (18), Vinnytsia (7), and Nemyriv districts (5). In 2017, these cooperatives provided services to rural residents for 15.3 million $\mathrm{UAH}$ and paid to the state 342 thousand UAH of taxes.

The Department of Agricultural Development of the Vinnytsia Regional State Administration has developed optimistic forecasts for the development of cooperatives in the region until 2020. In addition to existing ones, it is expected to create another 52 cooperatives.

In addition to cooperating and diversifying production, households have another way of "survival"; it is an opportunity to create on their basis family farms with the status of a certified agricultural producer. This is promoted by the Law of Ukraine "On Amendments to the Law of Ukraine "On Farming" on the Promotion of Establishment and Activity of Family Farming Enterprises", adopted on March 31, 2016, № 1067-VIII.
The Law stresses that farming enterprise can be established on the basis of business activity of all family members who carry out business activities and, therefore, it is a family farming enterprise. This form of management is subject to state registration as a legal entity - an entrepreneur.

Family farming enterprise without a legal entity status is organized by a sole proprietor independently or jointly with members of his or her family on the basis of an agreement on the establishment of a family farming enterprise. In the name of the family farmer without the status of a legal entity, the chairman of this household has the right to speak, or one of the members of the household authorized by him. The very process of creating a family farming enterprise provides conditions for an agreement on its identification in order to enter such a household and exit from it. In our view, the reformatting of households in rural farms is a rational solution to the problems of their implantation into the agrarian model of the development of the national economy.

Thus, today, the following forms of management in rural areas operate in parallel in Ukraine (Fig. 3).

Among the declared forms of economic management in the countryside, in our opinion, a family farming enterprise will be the most perspective in the future (Fig. 4).

The status of a certified agricultural producer of such a farm opens the way for direct financial assistance from the state and the civilized markets for food products (Law of Ukraine "On Amendments to the Law of Ukraine "On Farming”", 2016). In addition, there is an opportunity to get rid of the participation of intermediaries who buy up a lion's share of food from the population at a non-interest rate and resell it more expensive: vegetables - in four times, milk and meat of chickens - 2.5 times (Kyrylenko, 2016). One should also note that in the case of the creation of familyowned households on the basis of households, they receive special tax regimes, stimulate VAT, and then return themselves. The possibility of creating family farms will take place voluntarily with the status of a legal entity, or on a contractual basis. In this situation, experts suggest, perhaps, for the need to determine the level of state support, to recognize the three-tier level of the active actors of production: family farms, farms,

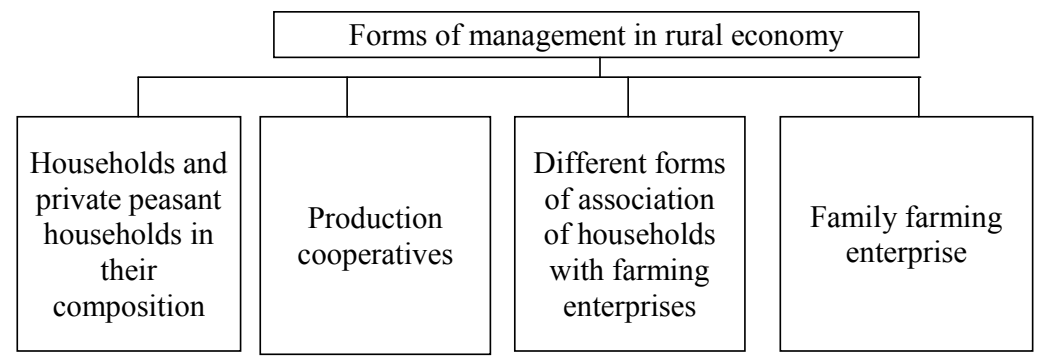

Fig. 3. Small forms of management in the AIC 


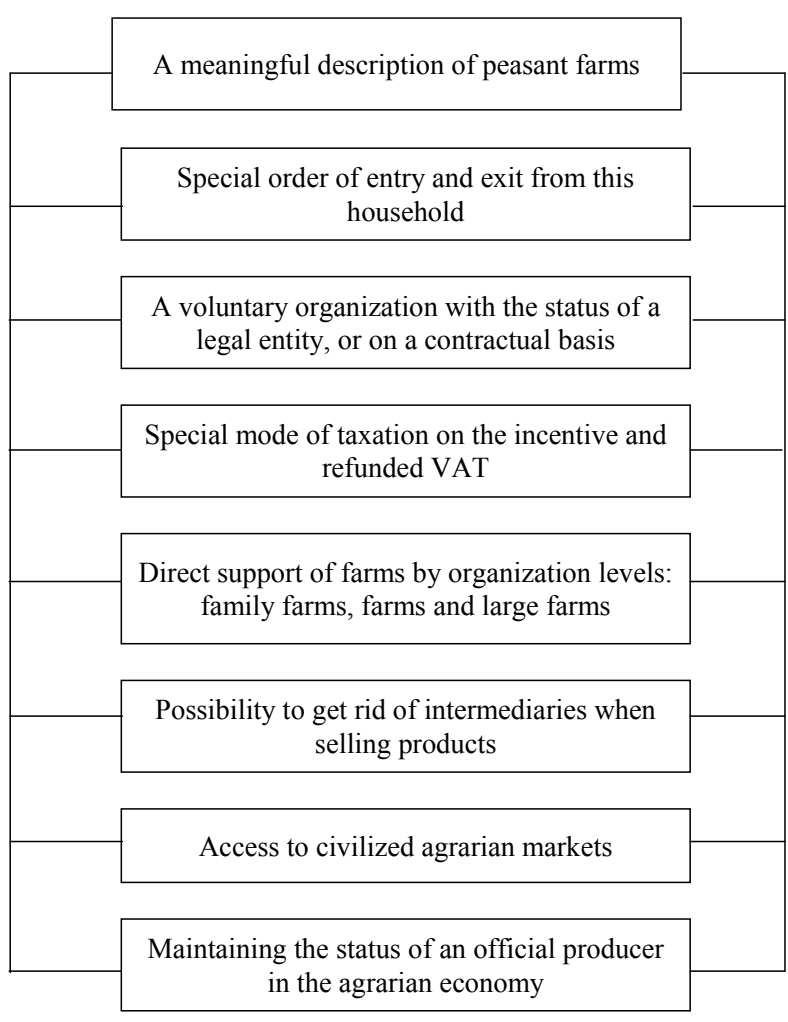

Fig. 4. Fragmentation of content and features of family farming enterprises

Source: the author's development

and large farms. The limit of sizes of family farming enterprises is proposed to be determined in 20 hectares of land use, farms - up to 10 thousand hectares, and large farms - starting with the area of 10 thousand hectares (Kyrylenko, 2016). It should be stressed that the fact of the organization of agricultural production on a family basis somehow goes around the Ukrainian legislation. This is not the case in the Laws of Ukraine "On Farming" and "On Personal Peasant Economy".

In our opinion, the Laws of Ukraine "On Agriculture" or "On Agricultural (Agrarian) System" should fill this gap, in which organizational principles of functioning of agricultural production should be written in a new way. The urgency of such a rule-making act is explained by the need to regulate agribusiness entities for their registration and exchange. Currently, the existing organizational structure in agrarian production, in general, does not adequately reflect the place of the agrarian market actors in the existing economic system. Thus, agricultural enterprises, which, on the basis of mergers or acquisitions, were included in the composition of agroholdings, do not know at all their status, and hence, in fact, lose their economic independence. The situation of uncertainty is also present in the system of households of the population when part of the personal peasant households that are included in them are actually engaged in the full-fledged commercial activity. At the same time, there is a reality of non-interception of family-type households to the existing system of functioning of the agrarian economy. Therefore, the priority rules of the above laws should be: formalization of modern farming enterprises as a form of organization of agricultural production; separation from the households of the population of private peasant farms engaged in commodity production, with their registration as subjects of economic practice and gradation on volumes of land ownership and production to justify the size of state support according to their size. As an additional rule-making measure, the personification of employment should be carried out and an effective social security mechanism for persons employed in these small-commodity entities should be introduced.

\section{Conclusions}

Discussions about the priority of certain organizational forms of management today are both about the expediency of creating large agrarian companies in the form of holdings, and the need to preserve small business forms in the AIC (farming enterprises, production cooperatives, private peasant farms). At the same time, the controversy on this issue is not completed. Governmental structures and the government in every way support large-scale production as more effective in relation to other organizational forms. At the same time, there is an opinion in society on the need to preserve small business forms of agrarian production in the future, since they are focused on the range of products that holdings do not deal with. Moreover, small business forms serve as "locomotives" of development of the rural economy, employment of population, and human development in the countryside. Under such conditions, legal and material support as a means of supporting economic practice in the countryside and the introduction of an effective state mechanism for stimulating industrial and economic practices in rural areas remain a relevant issue of the development of agrarian production.

The multivariance of organizational forms of agricultural production should provide for the possibility of transition from one to another, more appropriate form, which will prove its viability and efficiency in the process of the business activity. It is from this point of view that the development of organizational forms of economic management in the AIC should be considered. 


\section{References:}

Andriichuk, V.H. (2012) Ahropromyslovi formuvannia novoho typu v konteksti stratehii rozvytku vitchyznianoho silskoho hospodarstva [Agroindustrial formation of a new type in the context of the strategy of development of domestic agriculture]. Journal of Economy of agroindustrial complex, no. 1, pp. 3-15.

Bohotov, Kh. (2008) Yntehratsyia - harant uspeshnoho funktsyonyrovanyia khoziaistv naselenyia y upravlenyia [Integration is the guarantor of the successful functioning of households and the management]. vol. 11, pp. 36-39. Buriak, P. Yu. (2007) Intehrovani pidpryiemnytski struktury: formuvannia, efektyvnist, potentsial. [Integrated entrepreneurial structures: formation, efficiency, potential], Lviv: Logos (in Ukrainian).

Holyshev, M. (2000) Ahropromyshlennaia yntehratsyia v uslovyiakh mnohoukladnoi ekonomyky APK: ekonomyka y upravlenye [Agroindustrial integration in conditions of multistructure economy of agrarian and industrial complex: economy and management], vol. 4, pp. 51-56.

Tekst dlya Gosudarstvennyiy agropromyishlennyiy komitet (1998) Novyie promyishlennyie formirovaniya USSR perekladu [New industrial formations of the USSR]. Kyiv, pp. 61 (in Russian).

Verkhovna Rada Ukrainy (2016) «Pro vnesennia zmin do Zakonu Ukrainy «Pro fermerske hospodarstvo»» shchodo stymuliuvannia stvorennia ta diialnosti fermerskykh hospodarstv» ["On Amendments to the Law of Ukraine "On Farming" concerning the promotion of the establishment and operation of farms"] Zakon Ukrainy vid 31.03.2016, no. 1067-VIII.

Kyrylenko, I. H. (2016) Strukturni reformy na seli: svitovyi dosvid, ukrainski realii [Structural reforms in the countryside: world experience, Ukrainian realities] Journal of Economy of agroindustrial complex, vol. 2, pp. 5-11.

Kovalenko, V.L. (2012) Rozvytok intehratsiinykh protsesivu sferi APK Vinnychchyny [Development of integration processes in the field of agroindustrial complex Vinnytsya] Bulletin of Chernihiv State Technological University, vol. 2 (58), pp. 187-191.

Kulyniak, I. A. (2010) Kharakterystyka orhanizatsiino-pravovykh norm obiednan pidpryiemstv [Characteristics of organizational and legal forms of business associations] Scientific Bulletin of the National Academy of Sciences of Ukraine, vol. 20, pp. 199-204.

Parsiak, V. A. (2004) Polityka zrostannia ta rozvytku malykh ahropromyslovykh pidpryiemstv [The policy of growth and development of small agroindustrial enterprises] Journal of Economy of agroindustrial complex, vol. 10, pp. 56-63.

Pylypenko, A. A. (2008) Stratehichna intehratsiia pidpryiemstv: mekhanizm upravlinnia ta modeliuvannia rozvytku [Strategic integration of enterprises: management mechanism and modeling of development]. Charkiv: VDUNZHEK, (in Ukrainian).

Iurkevych, Yu. M. (2011) Hospodarski obiednannia: poniattia, vydy ta orhanizatsiino-pravovi formy [Economic associations: concepts, types and organizational and legal forms]. Scientific herald of Lviv State University of Internal Affairs, vol. 2, pp. 140-147. 